\title{
Teaching Grammar: Degrees of Adjective Comparisons in Secondary School of Indonesian Context
}

\author{
Muflihun \\ Queen's University of Belfast, United Kingdom
}

Abstract: This article explores the teaching grammar in secondary school in Indonesian context, the writer noticed that most of the students were struggling to clearly understand and unable to use comparison of adjective. Therefore, the writer would clearly explain those problems supported by research findings from previous studies. There are several activities to be used in teaching grammar, which surely could also be adapted to teaching adjective comparisons. However, in this essay, the writer would only address two common activities; namely grammar games and discovering grammar. It can be concluded that teaching grammar to some extent would not be complicated if it is delivered though appropriate teaching methods and deeply understand students' problems. Numerous engaging activities to teach grammar is available and this would shift our common paradigm of seeing learning and teaching grammar as a passive and 'old' fashioned thing to more communicative grammar teaching and learning.

Keywords: Teaching grammar, adjective comparision, grammar games, discovering grammar

\section{INTRODUCTION}

Learning English grammar for most of students in English as a foreign language context can be quite challenging. This is to some extent because there are numerous aspects of grammar which should be mastered gradually. Among of them is to understand the appropriate use of adjective, particularly in using it to express comparisons. Here in this essay, the author would highlight a common mistake made by learners while using adjective to state comparisons and ways to deal with these problems through applicable teaching methods.

In using comparison, we should be able to identify changes in suffix or spelling patters of adjective to state its degree. For example, to state an equal degree or positive form, we could use as . . .(adjective). . . as means that the things which are being compared are in equal degree. In addition, there are two major ways to express comparative meanings of adjective with one and two or more syllables. In the first place, we should add er for comparative and est for superlative forms in one syllable adjective. As outlined by Murphy (2012, p120) that $-\mathrm{er}$ is used for short adjective (one syllable) and more is used for longer adjective (two or more syllables). The last is about making comparisons with two 
or more syllables by adding more for comparative and most for superlative. These rules outlined above are categorized as regular comparison where changes of its levels largely depend on the suffixes or determiners which are being added. In contrast, irregular comparative forms are not simply by giving affixes or determiner on that adjectives, but it has own changes linguistically. A good example of this pattern would be the adjective of 'good-better-best'. Each of these words denotes comparative meanings sequentially.

To put it into brief ends, the following two tables provide summary of the degrees of comparisons. The first table would highlight regular comparisons which divided into two main sections based on its syllable, namely one syllable and two or more syllable. In addition, second table would manage the changes on irregular comparisons which also graded equally as positive, comparative and superlative forms.

Table 1. Regular Comparison (Adapted from: Sargeant, 2007:41)

\begin{tabular}{|c|c|c|c|}
\hline \multicolumn{2}{|r|}{ One syllable } & \multicolumn{2}{|c|}{ Two or more syllables } \\
\hline \multicolumn{4}{|c|}{ Example } \\
\hline Positive & $\begin{array}{l}\text { as...(adj.)...as: } \\
\text { - Your house is as big as } \\
\text { ours }\end{array}$ & Positive & $\begin{array}{l}\text { as...(adj.)...as: } \\
\text { - } \quad \text { Math is as difficult as } \\
\text { Chemistry }\end{array}$ \\
\hline Comparative & $\begin{array}{l}\text { adj.+ er than: } \\
\text { - Your house is bigger } \\
\text { than ours }\end{array}$ & Comparative & $\begin{array}{l}\text { more...(adj.) than: } \\
\text { - Math is more } \\
\text { difficult than English }\end{array}$ \\
\hline Superlative & $\begin{array}{l}\text { adj.+ est (preposition): } \\
\text { - Your house is the biggest } \\
\text { house in the city }\end{array}$ & Superlative & $\begin{array}{l}\text { most } \\
\text { preposition: } \\
\text { - Math is the most } \\
\text { difficult among other } \\
\text { subjects. }\end{array}$ \\
\hline
\end{tabular}

Table 2. Irregular Comparison (Adapted from: Sargeant, 2007:41)

\begin{tabular}{ccc}
\hline Positive & Comparative & Superlative \\
\hline good & better & best \\
\hline bad & worse & worst \\
\hline little & less & least \\
\hline many & more & most \\
\hline
\end{tabular}

*Additional Spelling rules will be given in appendix

As we could clearly see from these two tables, the changes in comparison appear in various ways. The more detailed changes into adjectives and spelling pattern would be given in the following passages. However, looking back at past teaching experiences in secondary school, the writer noticed that most of the students were struggling to clearly understand and unable to use comparison of adjective. This is, of course, caused by some problems which could not be easily concluded. Therefore, in the next essay, the writer would clearly explain those problems supported by research findings from previous studies. 


\section{DISCUSSION}

\section{The Nature of Teaching English Grammar}

Traditionally, it is accepted that teaching grammar lies at the root of Grammar Translation Method. This approach, however, has been considered as among the most classical methods in the early history of language teaching and learning. Larsen-Freeman and Anderson (2011, p13) argued that in the earlier of 20th century, Grammar Translation Method was firstly aimed at helping learners to read and to value foreign language literature. Through this method, they also hoped that by studying grammar of their target language, the students would gradually become more accustomed to the grammatical pattern of their native language. In addition, this familiarity then leads the students to be better at speaking or writing in their native language. This seems clear to be understood that learning grammar of target language either English or other languages requires a serious effort to comprehend grammatical pattern of our first language.

Teaching grammar has been considered as among the most essential part of the history of English language teaching and learning. This is supported by Rutherford (1988) (cited in Purpura, 2004, p1) who pointed out that grammar was initially used to understand the analysis of a language system, and the study of grammar was not just considered an essential feature of language learning, but was thought to be sufficient for learners to actually acquire another language. Therefore, we could assume that the term grammar is often used to refer to the complete set of rules needed to produce all the regular patterns in a given language.

According to Harmer (2015, p239) grammar teaching sometimes takes place due to other works that being done by the students. For instance, when the students are working on reading or listening to an audio, any particular grammar pattern would be unexpectedly found and a student is probably curious to learn about that. Therefore, as a language teacher, it would primarily become our responsibility to explain that point or at least being fully prepared to deal with any grammatical problems faced by our students.

\section{Understanding Comparative and Superlative}

As has been outlined in introduction, here in this section the author would briefly highlight common patterns and changes on adjective while it is used in comparisons. The following extracts, therefore, would be used as a guideline or be adapted in teaching degrees of comparison.

It is generally accepted that comparisons have different types depending on whether the things which are being compared are seen based on their differences or similarities. As Cowan (2008, p582) suggested that there are two main types of comparisons. The first is positive comparisons which divided into equality comparisons and inequality comparisons. The other is comparative and superlative forms. Below are the detailed differences of them.

\section{Equality and Inequality Comparisons}

When an adjective compares two things in an equal degree, then the addition of ...as...as... comes in the first place. Cowan (2008, p575-6) asserted that 
when we want to present two things as being equal in several aspects, we could express it by using ...as...as... which links the two things being compared. He then added that equality comparisons could also be stated trough a number of ways, for instance, by using be followed by the same + noun (thing) + as, similar to, equal/identical to, or (just) like. These patterns might be best expressed through following examples:

- My motorcycle is the same color as your motorcycle

- Andy's book is identical to mine

- You are just like my brother, etc.

However, in order to express an opposite meaning or inequality, we could simply insert not in the first clause. Therefore, after adding not to the sentences, the comparisons would be unequal. To exemplify these changes, let us consider the following sentences:

- My motorcycle is not the same color as your motorcycle

- Andy's book is not identical to mine

- You are not just like my brother.

Further, Cowan (2008, p574) explained that inequality comparison describes, for example, ' $x$ ' is greater than ' $y$ ' and conversely. This relation indeed underlies other ideas which Cowan (2008, p574) termed as superiority and inferiority. The former is usually expressed by the use of more or -er followed by than in comparative forms. The last is indicated by the use of less + (uncountable nouns) and fewer + (countable noun). Here are the examples:

- Airplane is faster than train (superiority)

- Alice has fewer friends than Nadine (inferiority)

Comparative Degree and Superlative Degree

Comparative degree describes unequal quality, size, measures or other respects of two nouns/things which are being compared. We could clearly see above, the formula of this comparison use one syllable adjective + er and more + two or more syllable adjectives. Murphy (2012, p210) asserted that we use -er for short adjective (one syllable) and use more for longer adjective (two or more syllables). Both of these patterns are completed by the use of than. Moreover, superlative degree takes a similar pattern. Murphy $(2012$, p216) added that we use - est for short adjectives and most for longer adjectives. Equally, these patterns would be followed by than and somehow by certain prepositions to clarify the scope or to what extent the comparison addressed. The prepositions might be like in, on, among, at, and others. In addition, the use of 'the' + short adjective (one syllable) is also crucially considered. To put it into practice, here are the examples.

- Going by plane is faster than by train

- Diamond is more expensive than gold

- Winter is the coldest season in a year

- New Year's celebration is the most enjoyable party in my life. 


\section{Irregular Comparisons of Adjective}

The other form in comparisons of adjective is irregular comparison. This type of comparison does not change regularly as shown by the other forms above and it also does not take more and most to signify comparative and superlative degree. It has its own changes and rules. Harrington (p.42) stated that a small number of highly frequent adjectives in irregular comparisons are bad - worse worst, good - better - best, far - further/farther - furthest/farthest, etc.

\section{Some Common Problems in Comparatives of Adjective}

While the author was teaching at a secondary school, he found that most of the students were having difficulties in understanding and using comparative adjective properly. This was, of course, caused by a number of factors which could not be simply concluded. However, as he had done some observation and carried out an informal in-depth interview with some of them, it was becoming increasingly apparent that this was because of several problems as he would mention here.

Firstly, they were unclear to differentiate the common pattern of adjective while it changed into degrees of comparison. It appeared when they tried to use comparative and superlative from. They could sometimes use two syllables of adjective + er to state comparative degree, instead of using adjective + -er only for one syllable. For instance, a student wrote, "My car is expensiver than their car". Another identifiable error which made by the students was doubling forms of determiner in comparisons. What do the writer meant by this is that they often use more or most followed by adjective with er or est endings. For example, some of them wrote "Plane is more faster that bus" or "My friend Adam is most tallest student in the class".

There are two researches on the adjective comparisons which carried out by Kacani (2014) and Al-Maani (2015). Kacani (2014) (cited in Al-Maani, 2015, p6) has investigated the most common grammatical problems made by Albanian students in their learning process. She found that one of most mistakenly understood by the students was incorrect use of comparative and superlative forms of the adjectives. The problems were in the use of adverb 'more/most' preceding single syllabic adjective and double syllabic adjectives added with -er or -est to state comparative or superlative. For instance, the students were found to use: 'this is more easier / more easy than.../ the most funniest', 'drive more faster' instead of 'this is easier than... / the funniest', 'drive faster'. Kacani emphasized that the learners were influenced by the Albanian language.

Further, Al-Maani (2015) studied about "The Acquisition of the Comparative and Superlative Adjectives by Jordanian EFL Students". The subjects of his study were 60 students from tenth graders schools (30 students) and second year college students (30 students). Then, the students were handed out 20 sentences which contained regular form of comparative and superlative using novel nonsense adjectives. The result of the study showed that university students to some extent mastered the rules more than their counterpart. In addition, both groups were better when it came to monosyllabic adjectives. However, when adjectives were polysyllabic, students' performance becomes worse. Al-Maani (2015, p11) concluded that the lower result gained by tenth 
graders because they learned English in their native language, i.e. Arabic. Therefore, they tend to apply comparison rules in Arabic to English they learned. In contrast, the university students were more exposed to English since it became language instruction in universities.

It becomes increasingly apparent to understand that first language or mother tongue of these students is to some extent influence their performances in using comparisons of adjective. They tend to over generalize or apply grammatical rules of their native language to English contexts. As mentioned by Larsen-Freeman (2001, p255) who argued that even though learners look to have comprehend or mastered a certain kind of grammatical structures, it is not rarely to find backsliding happens while introducing a new grammatical form to the learners. She illustrated that a student who has eventually mastered the third person singular markers of the present-tense verbs is possibly to over generalize the rule and to use it in currently modal verbs that he/she learns.

\section{Teaching Comparisons of Adjective}

In the writer's past learning experience contexts, teaching English grammar is mostly carried out by presenting grammar rules or explaining them gradually in separate phases. This first attempt is, then, followed by giving numerous examples and drillings to internalize those structures into students' understanding. Consequently, the students are hoped that they could be able to produce correct sentences grammatically. This well-known approach is called as Presentation Practice and Product or PPP. In an earlier series of his book, Harmer (2007, p64) asserted that the teacher begins the learning process by introducing a certain situation which contextualize the language that is being taught. Above all, this approach would be begun by giving clear presentation or lecture to the students about certain subjects that they learn. The students are gradually asked to practice the language pattern or structure in a number of ways such as choral repetition, individual repetition and cue-response drills. In the end, the students are encouraged to use the language form or patterns which they just learnt in a number of ways or contexts. This last stage would be called as 'production phase'.

The teaching procedure of PPP as mentioned above is considered to be similar with what is termed as 'Logical Line' lesson pattern. Scrivener (1994, p32) claimed that logical line lesson activities are a series of clear steps to be followed from one activity to the next. In working with grammar structure, for instance, the teachers or lecturers would constantly follow a sequence of activities which have been set beforehand in planning his lesson. Activity A would be about presenting or explaining an item of grammar, activity B is mainly about practicing it orally in drills, activity $\mathrm{C}$ would be in form of integrated speaking works and activity $\mathrm{D}$ would probably be designed as writing activity.

In dealing with those emerging problems as well as to confronting a traditional way of teaching grammar, the writer would highly suggest or be encouraged to use Task-Based Language Teaching in which more studentscentered and communicatively oriented. Larsen-Freeman and Anderson (2011, p150) addressed that 'task-based language teaching is example of the 'strong version' of the communicative approach where language is acquired trough use'. This teaching approach would be designed through providing a set of meaningful 
exercises which based on language focus or grammatical point. Further, they added these communicative tasks could be designed in various ways that encourage learners to notice specific language feature. This teaching technique considered appropriate in presenting language structures that are not easily understood, such as grammatical morphemes. This is in line with what has been stated by Richards and Rodgers $(2014, \mathrm{p} 175)$ that engaging students in a task work gives a better context for the activation of learning process than formfocused tasks and hence eventually provides essential circumstance for learning to take place.

There are several activities to be used in teaching grammar, which surely could also be adapted to teaching adjective comparisons. However, in this essay, the writer would only address two common activities. These are grammar games and discovering grammar. A brief teaching procedure and its implication could be given below.

\section{Grammar Games (Comparative Adjective)}

A number of grammar games are available for various handbooks in teaching grammar. This in line with Harmer (2015, p253) who claimed that many games from radio, television and some games that most people play at home could also be adapted for teaching purposes. In other words, any games could be designed based on grammar focus or aspect in which being taught to students. Comparative grammar game is considered essential to help students learning about degrees of comparisons in adjectives. To begin the teaching process, the teacher would introduce to the students about making comparisons in English. This can be done through several ways. For example, the teacher can ask two students - one student seems taller than his counterpart - to stand up next to each other and ask the class about who the taller one is. Then, to show superlative forms, the teacher may also ask the other tallest student to stand in line with those two students to indicate their differences in height.

Another way to exemplify comparisons, the teacher might also show some cities' landmarks which presented in power point slides. These pictures contain much key information related to these cities such as, density, transportation, skyscraper buildings, fashion price lists, public places, and the others. The teacher also includes a list of adjectives which supposed to be useful in comparing these cities. This last activity could be designed as competitive games in order to see how many comparative sentences that could be made by the students. In addition, the students might be put into group of three to four students to make them work together.

\section{Discovering Comparative Adjectives}

This section would be started by giving any reading material or passages which contain comparisons in adjective. Prior to teaching, the teacher should explain about adjective comparisons by indicating adjective ends either with -er or with -est and of course by determiner of more and most accompanying adjectives in these passages. Then, the students work in their group of three or more and they also list any comparisons they come across. The timing should also be set to give a limited sign of one activity to the others because after doing this they will compare their work with their friends in the other groups. Even probably 
they will find noun which ends with -er, for example, ...computer, worker, etc, this must be explained then by the teacher.

These two activities are adapted from the principals of Task-Based Language Teaching (TBLT) approach which highly acknowledge that learning process is focused on the task completion as the central of learning. This is primarily because a 'task' is seen as a medium of learning. Additionally, Edwards and Willis $(2005, \mathrm{p} 3)$ defined that a 'task' can involve any or all four language skills which are listening, speaking, reading and writing. In other words, taskbased language teaching approach is adaptable to all language skills which in its implementation language components such as grammar, vocabulary, pronunciation and others would be highly considered.

\section{CONCLUSION}

In the end, the writer would state that teaching grammar to some extent would not be complicated if it is delivered though appropriate teaching methods and deeply understand students' problems. Numerous engaging activities to teach grammar is available and this would shift our common paradigm of seeing learning and teaching grammar as a passive and 'old' fashioned thing to more communicative grammar teaching and learning.

\section{REFERENCES}

Al-Maani, A. (2015). The acquisition of the comparative and superlative adjectives by Jordanian Efl students. Language in India, 16(1). Available at: https://eis.hu.edu.jo/deanshipfiles/pub112017677.pdf

Cowan, R. (2008). The teacher's grammar of English a course book and reference guide. Cambridge: Cambridge University Press.

Edward, C. \& Willis, J. (2005). Teachers exploring task in English language teaching. Hampshire: Palgrave Macmillan.

Harmer, J. (2007). The practice of English language teaching (4th edition). United Kingdom: Pearson Education Limited.

Harmer, J. (2015). The practice of English language teaching ( $5^{\text {th }}$ edition). England: Pearson Education Limited.

Harrington, K. (2018). Fifty pages survival English grammar for ESOL tutors and students. Galway: CGVEC, Seville House.

Larsen-Freeman, D. (2001). Teaching grammar. In Celce-Murcia, M. (Eds) Teaching English as a second or foreign language. Heinle \& Heinle: Thomson Learning.

Larsen-Freeman, D. \& Anderson, M. (2011). Techniques and principles in language teaching ( $3^{\text {rd }}$ edition). United Kingdom: Oxford University Press. 
Murphy, R. (2012). English grammar in use: A self-study reference and practice book for intermediate learners of English (4 ${ }^{\text {th }}$ edition). Cambridge: Cambridge University Press.

Purpura, J. E. (2004). Assessing grammar. Cambridge: Cambridge University Press.

Richards, J.C. \& Rodgers, T.S. (2014). Approaches and methods in language teaching $\left(3^{\text {rd }}\right.$ edition). Cambridge, United Kingdom: Cambridge University Press.

Sargeant, H. (2007). Basic english grammar for English language learners. United States: Saddleback Educational Publishing.

Srivener, J. (1994). Learning teaching. a guide book for English language teachers. Oxford: Heinemann Publisher. 